\section{Kontribusi Teologi Kepemilikan dan Fungsi Kekayaan Menurut Lukas bagi Upaya Pengentasan Kemiskinan di Indonesia}

\author{
Vasika Hananti \\ Sekolah Tinggi Teologi Sriwijaya \\ hanantivasika@yahoo.com
}

\begin{abstract}
The problem of poverty in Indonesia is still unresolved to date. Related to the problem of poverty, ideas emerge in an effort to alleviate poverty that focuses on empowerment, entrepreneurship and deacons. These three ideas of thought can lead to dangers, including: empowerment and entrepreneurship can trigger the spirit of capitalism which can lead to greed and high egocentrism. Whereas deacons can make people keep silent without the effort to move out of poverty. So that the three concepts of poverty alleviation do not fall into this danger, it is necessary to provide a basis for thinking about the theology of ownership and the function of wealth. One of the books that could provide a prospect for rationale is the book of Luke. The book of Luke leaves ample room for discussion of the theology of property and function of wealth. In this paper, the author uses a qualitative approach with a descriptive analysis method. The result of this research is that the book of Luke contributes thoughts about the theology of ownership and the function of wealth. His contribution is that in Luke's writings there is a systemic pattern that was born from the theology of property and function of wealth. This systemic pattern can contribute to the idea that the church can create a poverty alleviation system that not only works on an individualistic level, but also has a communal dimension that involves poor and rich people in order to create a community without social disparities.
\end{abstract}

Keywords: Ownership theology; wealth function theology; empowerment; entrepreneurship; diakonia; poverty

Abstrak: Persoalan kemiskinan di Indonesia masih belum terselesaikan hingga saat ini. Terkait
masalah kemiskinan ini muncul gagasan pemikiran dalam upaya mengentaskan kemiskinan
yang berfokus pada pemberdayaan, kewirausahaan dan diakonia. Ketiga gagasan pemikiran ini
dapat mengarah pada bahaya, diantaranya: pemberdayaan dan kewirausahaan dapat memicu
semangat kapitalisme yang dapat menimbulkan keserakahan dan egosentrisme yang tinggi.
Sedangkan diakonia dapat membuat orang untuk berdiam diri tanpa daya upaya untuk beranjak
dari kemiskinannya. Agar ketiga konsep pengentasan kemiskinan itu tidak jatuh pada bahaya
tersebut, maka perlu memberikan landasan pemikiran tentang teologi kepemilikan dan fungsi
kekayaan. Salah satu kitab yang dapat memberikan prospek landasan pemikiran adalah kitab
Lukas. Kitab Lukas memberi ruang yang besar untuk membicarakan tentang teologi
kepemilikan dan fungsi kekayaan. Dalam tulisan ini, penulis menggunakan pendekatan kualitatif
dengan metode deskriptif analisis. Hasil penelitian ini adalah kitab Lukas memberikan
kontribusi pemikiran tentang teologi kepemilikan dan fungsi kekayaan. Kontribusinya adalah 
dalam tulisan Lukas terdapat adanya suatu pola sistemik yang dilahirkan dari teologi kepemilikan dan fungsi kekayaan. Pola yang sistemik tersebut dapat menyumbangkan pemikiran agar gereja dapat membuat suatu sistem pengentasan kemiskinan yang tidak hanya bekerja pada aras individualistik, melainkan juga memiliki dimensi komunal yang melibatkan orang-orang miskin dan kaya untuk dapat menciptakan komunitas yang tanpa kesenjangan sosial.

Kata kunci: Teologi kepemilikan; teologi fungsi kekayaan; pemberdayaan; kewirausahaan; diakonia; kemiskinan

\section{Pendahuluan}

Kemiskinan di Indonesia sampai sekarang masih menjadi masalah yang belum terselesaikan. Hal ini dapat digambarkan dari data menurut Badan Pusat Statistik (BPS), yaitu: jumlah penduduk miskin di Indonesia pada dari Septemper 2019-Maret 2020 meningkat menjadi 26,42 juta orang. Peningkatannya dari September 2019-Maret 2020 adalah sebesar 1,63 juta orang. Jadi persentasenya naik menjadi 9,78 persen. ${ }^{1}$

Terkait dengan persoalan kemiskinan ini, para teolog dan pemerhati kemiskinan ikut menyumbangkan gagasan-gagasan pemikiran dalam upaya gereja menyikapi persoalan kemiskisan. Beberapa teolog dan pemerhati kemiskinan telah membangun konsep pemikiran dengan fokus yang berbeda-beda. Pertama, pemberdayaan. Grace Sumbung dan kawan-kawannya menganggap bahwa pemberdayaan adalah satu cara yang dapat diimplementasikan dan dikembangkan dalam kegiatan pembangunan. ${ }^{2}$ George Marthen Likumahwa bersama dengan John A. Titaley dan Steve Gaspersz, ${ }^{3}$ dan Fibry Jati Nugroho juga memberikan perhatiannya terhadap pemberdayaan. ${ }^{4}$ Dari para teolog ini dapat dipahami bahwa pemberdayaan itu dapat berupa pemberdayaan ekonomi, pemberdayaan dengan memupuk spiritualitas ugahari, dan pemberdayaan dengan meningkatkan spiritualitas jemaat.

Kedua, kewirausahaan. Simon Julianto adalah salah satu teolog yang memusatkan penelitiannya tentang praktek kewirausahaan jemaat. Julianto memandang positif dan terbuka terhadap kewirausahan dalam gereja. ${ }^{5}$ Pemerhati kemiskinan lain yang mengarah kepada kewirausahaan adalah Erman S. Saragih yang menekankan pada entrepreneur sosial. ${ }^{6}$ Para teolog ini memandang bahwa kewirausahan merupakan cara yang tepat dipakai dalam gereja untuk mengatasi kemiskinan. 15 Juli 2020.

${ }^{1}$ BPS, Berita Resmi Statistik: Profil Kemiskinan Di Indonesia Maret 2020, No. 56/07/Th. XXIII,

${ }^{2}$ Grace Sumbung, dkk., "Peran Gereja dalam Peningkatan Ekonomi Masyarakat di Tomohon Sulawesi Utara,” Jurnal Wacana, Vol. 15, No. 4, (2012), 8-14.

${ }^{3}$ George Marthen Likumahwa, John A. Titaley dan Steve Gaspersz, "Keluar dari Kemiskinan: Studi Pembangunan dan Pemberdayaan Jemaat di Dususn Siahari, Kecamatan Seram Utara Timur," Arumbae: Jurnal Ilmiah Teologi dan Studi Agama, Vol. 2, No. 1 (2020).

${ }^{4}$ Fibry Jati Nugroho, "Gereja dan Kemiskinan: Diskursus Peran Gereja di Tengah Kemiskinan," Engelikal: Jurnal Teologi Injili dan Pembinaan Warga Jemaat, Vo. 3, No. 1 (Januari 2019).

${ }^{5}$ Simon Julianto, "Kewirausahaan Jemaat: Sebuah Alternatif Berteologi," WASKITA, Jurnal Studi Agama dan Masyarakat, 151-183.

${ }^{6}$ Erman S. Saragih, "Fungsi Gereja Sebagai Entrepreneurship Sosial dalam Masyarakat Majemuk," Kurios: Jurnal Teologi dan Pendidikan Agama Kristen, Vol. 5, No. 1 (April 2019), 12-23. 
Ketiga adalah diakonia. Mariani Febriana berusaha untuk mengembangkan konsep tentang pietas dan caritas. Pietas dan caritas ini diwujudkan dalam pelayanan diakonia sebagai suatu cara yang dapat diwujudkan melalui kepedulian sosial gereja dalam meretas angka kemiskinan di Indonesia. ${ }^{7}$ Selain Febriana, Nimrot Doke Para bersama dengan Ezra Tari dan Welfrid F. Ruku memberi perhatian tentang peran gereja dalam pelayanan diakonia secara khusus diakonia transformatif. ${ }^{8}$ Peranan diakonia juga disuarakan oleh Alon Mandimpu Nainggolan. Ia berusaha untuk memadukan bentuk diakonia karitatif dan transformatif sebagai upaya warga gereja dan masyarakat yang menderita akibat bencana non alam Covid-19. ${ }^{9}$

Para teolog di atas, baik itu yang berfokus pada pemberdayaan, kewirausahaan dan diakonia, pada umumnya gagasan pemikirannya bertolak dari orang-orang miskin. Pemberdayaan dan kewirausahaan mengarah kepada dorongan seseorang untuk bekerja dengan giat. Sedangkan diakonia berusaha untuk memberi kepada orang-orang yang berkekurangan dan membutuhkan sebagai wujud belas kasihan.

Ketiga hal ini adalah konsep yang baik untuk mendorong gereja dalam upaya mengatasi kemiskinan. Namun sayangnya, pengentasan kemiskinan yang berbasis pemberdayaan dan kewirausahaan dapat memacu semangat kapitalisme yang dapat membahayakan, seperti muncul sifat serakah, hawa nafsu yang tinggi, tipu daya, kejahatan, dll. ${ }^{10}$ Sedangkan diakonia dapat memancing para penerima diakonia untuk tetap berdiam diri, tanpa usaha, sehingga tidak dapat berdaya upaya dalam mengentaskan diri dari kemiskinannya sendiri.

Bahaya yang dilahirkan dari ketiga gagasan pemikiran pengentasan kemiskinan ini sebenarnya terindikasi juga dalam Dokumen Keesaan Gereja PGI (Persekutuan Gereja-gereja Indonesia) yaitu pada Pokok-pokok Tugas Panggilan Bersama (PTPB) dalam DKG-PGI tahun 2019-2024 bab 5 ayat 93, yang berisi tentang gereja perlu membangun etos hidup keugaharian agar dapat menahan gaya hidup konsumerisme dan keserakahan, serta gaya hidup yang ramah lingkungan. ${ }^{11}$ Spiritualitas ugahari sebenarnya juga merupakan semangat untuk mendorong seseorang menumpuk

\footnotetext{
${ }^{7}$ Mariani Febriana, "Pietas dan Caritas: Pelayanan Diakonia Sebagai Suatu Implementasi Kepedulian Sosial Gereja Untuk Menolong Meretas Angka Kemiskinan Di Indonesia," Jurnal Theologi Aletheia, Vol. 16, No. 7 (September 2014), 45-69.

${ }^{8}$ Nimrot Doke Para, dkk., "Peran Gereja dalam Transformasi Pelayanan Diakonia," Jurnal Teologi Kontekstual Indonesia, Vol. 1, N. 1 (2020), 81-93.

${ }^{9}$ Alon Mandimpu Nainggolan, "Model Diakonia Gereja di Tengah Pandemi Covid-19: Sebuah Upaya Mitigasi Bencana Alam Non Alam,” Putewaya: Jurnal Sosiologi Agama, Vol. 1, No. 1 (2020), 4055.

${ }^{10}$ Sebagaimana yang diungkapkan oleh Joseph W.H. Lough, Weber and the Persistence of Religion: Social Theory, Capitalism, and the sublime (London and New York: Routledge, 2006), 40-55.

${ }^{11}$ PGI, Dokumen Keesaan Gereja (DKG-PGI) 2014-2019, 16-17 dan 56-58. Dalam Dokumen Keesaan Gereja (DKG-PGI) 2019-2024 (Jakarta: BPK Gunung Mulia, 2020), 47-50.
} 
kekayaan. Dari keugaharian ini dapat memunculkan sifat keserakahan. Perlu diingat bahwa awal mula munculnya kapitalisme adalah dari semangat hidup yang ugahari ini. ${ }^{12}$

Dalam mewujudkan keadilan dan kesejahteraan rakyat, PGI juga menyatakannya dalam DKG tentang Komitmen Keesaan Gereja Anggota PGI yang termuat di dalam Bab 1 pasal 11 tentang pelayanan diakonia. ${ }^{13}$ Hal ini juga dapat menimbulkan bahaya seperti kemalasan pada diri seseorang.

Agar ketiga konsep pengentasan kemiskinan itu tidak jatuh pada bahaya ketamakan dan kemalasan, maka perlu memberikan landasan pemikiran tentang teologi kepemilikan dan fungsi kekayaan. Salah satu kitab yang dapat memberikan prospek landasan pemikiran adalah kitab Lukas. Kitab Lukas memberi ruang yang besar untuk membicarakan tentang teologi kepemilikan dan fungsi kekayaan. Sebagai contoh teologi kepemilikan mencul dalam Lukas 12:35-48; 16:1-9 dan Kisah Para Rasul 2:42-47. Sedangkan untuk teologi fungsi kekayaan muncul dalam Lukas 6:24; 12:13-21; 15:1-32; 16:1-13 dan 19:31; 18:18-27; 19:1-10.

Melalui tulisan ini, penulis berpendapat bahwa kitab Lukas memberikan kontribusi pemikiran tentang teologi kepemilikan dan fungsi kekayaan. Dalam tulisan Lukas terdapat adanya suatu pola sistemik yang dilahirkan dari teologi kepemilikan dan fungsi kekayaan. Pola yang sistemik tersebut dapat menyumbangkan pemikiran agar gereja dapat membuat suatu sistem pengentasan kemiskinan yang tidak hanya bekerja pada dimensi individual, melainkan juga memiliki dimensi komunal yang melibatkan orang-orang miskin dan kaya untuk dapat menciptakan komunitas yang tanpa kesenjangan sosial.

\section{Metode Penelitian}

Penelitian ini bersifat kualitatif dengan menggunakan metode deskriptif-analitis. Metode deskriptif merupakan metode yang berupaya untuk menguraikan objek kajian tanpa ada evaluasi. Namun kemudian, metode ini dilengkapi dengan upaya analisis dalam rangka menganalisis data yang ada untuk membuat analisis kritisnya. ${ }^{14}$ Dalam penelitian ini, metode deskriptif dilakukan untuk menguraikan gagasan-gagasan pemikiran pengentasan kemiskinan di Indonesia. Kemudian penulis juga akan melihat bagaimana konsep teologi kepemilikan dan fungsi kekayaan dalam kitab Lukas yang berguna untuk melengkapi konsep-konsep yang telah berkembang selama ini. Untuk mencapai maksud tersebut, diperlukan juga langkah analitis terhadap gagasan-gagasan pengentasan kemiskinan tersebut dan kemudian mengevaluasinya dengan perspektif konsep teologi kepemilikan dan fungsi kekayaan dalam Lukas.

\footnotetext{
${ }^{12}$ Lihat dalam karya Max Weber, The Protestant Ethic and the Spirit of Capitalism (London and New York: Routledge, 2001), 53-80. (terjemahan dalam Bahasa Ingris). 2024, 47-50.

${ }^{13}$ PGI, Dokumen Keesaan Geeja; Persekutuan Gereja-Gereja di Indonesia (DKG-PGI) 2019-

${ }^{14}$ Kothari, C., Research Methodology: Methods and Techniques (New Delhi: New Age International Limited Publisher, 2004), 4.
} 


\section{Hasil dan Pembahasan}

\section{Konsep-konsep dalam Pengentasan Kemiskinan}

Kesatu, Pemberdayaan. Grace Sumbung bersama dengan Agus Suman, Kliwon Hidayat dan Paulus Kindangen melakukan analisa bagaimana peran Gereja Masehi Injil di Indonesia (GMIM) dalam memberdayakan masyarakat sekitar kota Tomohon, Sulawesi Utara, yang mendirikan BLT (Training Center) Kaaten - Tomohon berdasarkan pengolahan kelapa-kayu. Pemberdayaan tersebut berupa pemberdayaan ekonomi. $^{15}$

Selain itu, George Marthen Likumahwa bersama dengan John A. Titaley dan Steve Gaspersz melihat adanya kemiskinan di dusun Siahari, kecamatan Seram, Utara Timur. Mereka melihat bahwa upaya pemerintah selama ini hanya terletak pada tindakan-tindakan penanggulangan yang hanya bersifat darurat. ${ }^{16}$ Begitu juga, Gereja Protestan Maluku (GPM) cenderung berorientasi pada pemberian bantuan melalui diakonia karitatif kepada keluarga yang miskin. ${ }^{17}$

Melihat kemiskinan yang terjadi di daerah ini, Likumahwa bersama Titaley dan Gaspersz mengatakan bahwa gereja berperan untuk memperjuangkan hak-hak hidup umat manusia. Dalam hal ini, GPM terpanggil untuk ikut membantu orang-orang yang mengalami kemiskinan. Karena itu GPM harus menjadi sumber kesejahteraan dalam tindakan pemberdayaan agar dapat menciptakan perubahan bagi kehidupan bersama. ${ }^{18}$

Salah satu ketetapan yang dapat digunakan sebagai model pemberdayaan umat adalah membentuk kemitraan lintas jemaat. Dalam hal ini gereja harus dapat menjadi fasilitator, mediator dan transformator. Dalam hal ini, gereja dapat melakukan pemberdayaan melalui pelayanan kasih yang terwujud dalam bentuk diakonia transformatif. ${ }^{19}$

Fibry Jati Nugroho juga memiliki konsep bahwa pemberdayaan merupakan sebuah upaya yang dapat dipakai oleh gereja untuk memerangi kemiskinan. ${ }^{20}$ Menurutnya, tugas dan panggilan gereja adalah memperhatikan orang-orang miskin. Selain itu, baginya juga ketika gereja dapat memberdayakan jemaatnya, maka gereja juga meningkatkan spiritualitas jemaatnya. ${ }^{21}$

Berdasarkan uraian di atas dapat disimpulkan bahwa gereja harus memiliki peran untuk memberdayakan jemaat dalam upaya menghadapi persoalan kemiskinan. Ada dua

\footnotetext{
${ }^{15}$ Grace Sumbung, dkk., "Peran Gereja dalam Peningkatan Ekonomi Masyarakat di Tomohon Sulawesi Utara," Jurnal Wacana.

${ }^{16}$ George Marthen Likumahwa, John A. Titaley dan Steve Gaspersz, "Keluar dari Kemiskinan: Studi Pembangunan dan Pemberdayaan Jemaat di Dusun Siahari, Kecamatan Seram Utara Timur," Arumbae: Jurnal Ilmiah Teologi dan Studi Agama, Vol. 2, No. 1.

${ }^{17}$ Ibid.

${ }^{18}$ Ibid.

${ }^{19}$ Ibid.

${ }^{20}$ Fibry Jati Nugroho, "Gereja dan Kemiskinan: Diskursus Peran Gereja di Tengah Kemiskinan," Evangelikal: Jurnal Teologi Injili dan Pembinaan Warga Jemaat.

${ }^{21}$ Ibid.
} 
bentuk pemberdayaan yang dapat dilakukan dalam gereja, diantaranya: pertama, pemberdayaan ekonomi dan pemberdayaan jemaat dengan memupuk spiritualitas ugahari. $^{22}$ Pada dasarnya, pemberdayaan merupakan model pembangungan masyarakat yang berbasis kerakyatan dengan tujuan untuk meningkatkan harkat dan martabat masyarakat yang terperangkap dalam soal kemiskinan dan keterbelakangan. ${ }^{23}$ Tujuan dari pemberdayaan ekonomi tentunya adalah untuk meningkatkan perekonomian. Masyarakat didorong untuk meningkatkan perekonomian mereka. Cara ini mendorong masyarakat untuk menjadi kaya. Jika tidak dikendalikan, maka akan jatuh pada bahaya keserakahan.

Sedangkan, pemberdayaan dengan mempupuk spiritualitas keugaharian dilakukan dengan menekan pemborosan atau budaya konsumerisme. Namun, perlu diingat bahwa awal mula munculnya kapitalisme adalah dari semangat hidup yang ugahari ini. Seperti dalam Calvinisme dipahami bahwa manusia perlu melaksanakan "tapa-brata duniawi" (this worldly asceticism), yaitu suatu bentuk pengendalian diri. ${ }^{24}$ Salah satu contoh bentuk pengendalian diri terwujud dalam sikap hidup hemat, mengumpulkan materi untuk usaha, menabung, suka bekerja keras, saling membantu, tidak menuntut imbalan. Sikap-sikap ini merupakan contoh dari ketaatan transendental dari para penganut protestan. Karena itu, ketaatan ini dapat dilihat dari keinginan dan etos kerja yang dimilikinya. Dalam ajaran Calvinis menekankan sikap-sikap asketisme dengan tujuan agar manusia tidak jatuh dalam dosa. Dengan demikian, askestisme ini dapat mendorong semangat kapitalisme, seperti berproduksi, menyimpan keuntungan, dll. Dalam hal ekonomi, mereka didorong untuk hidup hemat agar dapat mengumpulkan modal yang sebanyak-banyaknya untuk bertahan hidup. Namun, kemudian terjadi penumpukan modal dari setiap masing-masing individu. Jadi, dapat dikatakan bahwa agama memiliki kontribusi yang besar mengembangkan perilaku ekonomi masyarakat, khususnya kapitalisme. Weber menunjukan bahwa kemajuan ekonomi pada masyarakat Barat tidak hanya dipengaruhi kelompok bisnis dan pemodal, tetapi juga keberagamaan Protestan, yang dalam spirit keagamaannya mengandung rasionalitas ekonomi. ${ }^{25}$

Faktanya adalah pelopor pertama kapitalisme adalah individu yang sangat religius yang menunjukkan ketidakpercayaan keterikatan pada harta benda. Weber menunjukkan bagaimana individu historis ini, 'roh' kapitalisme, pada kenyataannya telah mendominasi totalitas kehidupan sosial. Nilai religius ditempatkan pada kerja tanpa

${ }^{22}$ Spiritualitas keugaharian dipahami tidak hanya dalam arti sederhana, tetapi lebih pada gagasan tentang etos hidup berkecukupan atau self-sufficient. Penjelasan oleh George Marthen Likumahwa, John

A. Titaley dan Steve Gaspersz, "Keluar dari Kemiskinan: Studi Pembangunan dan Pemberdayaan Jemaat di Dususn Siahari, Kecamatan Seram Utara Timur," Arumbae: Jurnal Ilmiah Teologi dan Studi Agama, Vol. 2, No. 1. 89.

${ }^{23}$ Munawar Noor, “Pemberdayaan Masyarakat,” Jurnal Ilmiah CIVIS, Vol. I, No. 2 (Juli 2011),

${ }^{24}$ Lihat dalam karya Max Weber, The Protestant Ethic and the Spirit of Capitalism, 53-80. (terjemahan dalam Bahasa Ingris).

${ }^{25}$ Ibid, 54-125. 
henti, konstan, sistematis dalam panggilan sekuler. Weber mencatatnya sebagai jalan pertapa tertinggi. Namun, individu juga dilarang terlibat dalam kegiatan yang dapat dinilai boros, tidak produktif dan tamak. Sementara mendukung produksi kekayaan ekonomi swasta, menurut Weber, asketisme bertentangan dengan ketidakadilan dan keserakahan murni naluriah. Lebih penting lagi, jika pembatasan konsumsi itu dikombinasikan dengan kebebasan untuk memperjuangkan keuntungan, hasil yang ditimbulkan adalah penciptaan modal melalui keharusan orang untuk menabung. ${ }^{26}$

Dengan demikian, semangat keugaharian yang diusulkan oleh George Marthen dan teman-temannya, justru dapat menimbulkan kekhawatiran, yaitu agama dapat secara tidak sadar dapat mendorong semangat kapitalisme ini. Dalam bahasa Lough, agama dapat melahirkan nilai-nilai sekularisasi yang membahayakan. Dari semangat spritualitas ugahari ini dapat menimbulkan penumpukkan harta pada satu sisi (semangat kapitalisme) hingga tidak mencapai kepuasan. Dalam bahasa Kant, the sublime melahirkan nilai-nilai sekulerisasi dalam agama seperti keserakahan. ${ }^{27}$ Pada akhirnya dapat menciptakan kesenjangan sosial antara yang dapat menumpuk harta dan yang tidak dapat mengumpulkan harta.

Pemberdayaan ekonomi dan spiritualitas ugahari, kedua-duanya dapat menimbulkan bahaya kapitalisme. Jika tanpa kendali, maka kedua-duanya berada pada persoalan yang sama, yaitu penumpukan harta kekayaan. Penumpukan yang tidak terkendali tetap saja dapat membuat jurang antara yang kaya dan yang miskin.

Kedua, Kewirausahaan. Simon Julianto merupakan salah seorang yang melihat sisi baik wirausaha dalam gereja. Ia merasa penting untuk membangun sebuah teologi alternatif yang menjembatani diskusi dunia bisnis dengan dunia gereja. ${ }^{28}$ Julianto berpijak pada proses berteologi yang diajarkan oleh Banawiratma ketika menyebut Teologi Kewirausahaan. Teologi Kewirausahaan merupakan sudut pandang agama untuk memahami praktik kewirausahaan. ${ }^{29}$

Dalam membangun teologinya, Julianto mencoba memaknai pengalaman jemaat, yaitu Gereja Kristen Protestan Bali (GKPB) dan Gereja Kristen Jawa (GKJ) dalam melakukan praktik berwirausaha. Julianto menemukan dasar berteologi kewirausahan, diantaranya: Teopreneur (Allah sebagai figur enterpreneur), Christopreneur (melihat sisi enterpreneur Kristus), dan melihat Paulus sebagai teladan wirausaha. Dengan berteologi ini, Julianto ingin mendorong percakapan praktik kewirausahaan di jemaat, dan mendorong semakin giatnya upaya untuk menggali dasar-dasar teologis kewirausahaan jemaat. $^{30}$

\footnotetext{
${ }^{26}$ Dalam penjelasan Joseph W.H. Lough. Weber and the Persistence of Religion: Social Theory, Capitalism, and the sublime (London and New York: Routledge, 2006), 40-45.

${ }^{27}$ Ibid, 103-111.

${ }^{28}$ Simon Julianto, "Kewirausahaan Jemaat: Sebuah Alternatif Berteologi," WASKITA: Jurnal Studi Agama dan Masyarakat.

${ }^{29}$ Ibid.

${ }^{30}$ Ibid.
} 
Selain itu, Erman S. Saragih memberi penekanan pada entrepreneur sosial yang merupakan salah satu model diakonia untuk membuat hubungan antara yang bergelut dalam bidang produksi dan konsumsi dengan menekankan pada persamaan. ${ }^{31}$ Dari sini dimengerti bahwa gereja perlu berfikir secara inovatif dan kreatif untuk melihat peluang-peluang usaha. ${ }^{32}$ Akan tetapi, sifat kewirausahan juga dapat menimbulkan kekhawatiran, yakni ambisi penciptaan kekayaan yang terus-menerus hingga menimbulkan sifat ketamakan. Hal ini juga dapat jatuh kepada bahaya kapitalisme.

Ketiga, Diakonia. Mardiani Febriana mengutip dari Noordegraaf menjelaskan bahwa diakonia merupakan pelayanan gereja yang penting di mana teologi menjadi dekat dengan realitas kehidupan manusia. ${ }^{33}$ Pietas dan caritas adalah hidup beribadah dalam realita sosial. Ibadah orang percaya nyata dalam tindakan konkretnya kepada sesama, yang tidak hanya eksklusif, tetapi juga inklusif yang diwujudkan dalam memperhatikan orang miskin. ${ }^{34}$

Selain itu, Alon Mandimpu Nainggolan berusaha mendeskripsikan model diakonia gereja. ${ }^{35}$ Ia melihat bahwa diakonia yang relevan untuk situasi bencana alam non alam (seperti Covid-19) adalah diakonia integratif antara diakonia karitatif dengan diakonia transformatif. Hal ini didasarkan pada pemikiran bahwa sebagian warga gereja beranggapan bahwa ketika mereka mengalami penderitaan berat akibat bencana alam non alam Covid-19, maka yang dibutuhkan adalah uluran tangan yang nyata, misalnya pemberian bantuan pangan, biaya kesehatan, biaya pendidikan anak, dll. Namun, sebagian warga gereja juga berpikir bahwa yang diperlukan adalah instrumen-instrumen pelayanan agar mereka bisa keluar dari penderitaan mereka. Ada juga pemikiran yang lain bahwa tidak cukup hanya memberikan bantuan dalam bentuk uang, sembako, dll, melainkan perlu juga adanya pikiran-pikiran kreatif dan inovatif untuk memberdayakan umat agar dapat keluar dari permasalahan yang dialami. Atas dasar fenomena dan fakta yang terjadi, Nainggolan memandang bahwa model diakonia karitatif dan transformatif adalah hal yang tidak bisa dipisahkan, namun terintegrasi ketika umat mengalami bencana non alam. ${ }^{36}$

Para teolog yang berkonsentrasi pada pentingnya peran diakonia dapat disimpulkan bahwa diakonia merupakan aspek pelayanan gereja yang dapat mendekatkan teologi dengan realitas manusia. Sebenarnya dalam bentuk apapun,

${ }^{31}$ Erman S. Saragih, "Fungsi Gereja Sebagai Entrepreneurship Sosial dalam Masyarakat Majemuk," Kurios: Jurnal Teologi dan Pendidikan Agama Kristen.

${ }^{32}$ Mengenai inovatif dan kreatif dalam wirausaha lihat Wee-Liang Tan, John Williams, and TeckMeng Tan, "Defining Social in Social Enterpreneurship: Altruisme and Entrepreneurship," International Entrepreneurship and Management Journal (2005), 323-365.

${ }^{33}$ Mardiani Febriana, "Pietas dan Caritas: Pelayanan Diakonia Sebagai Suatu Implementasi Kepedulian Sosial Gereja untuk Menolong Meretas Angka Kemiskinan di Indonesia," Jurnal Theologi Aletheia.

34 Ibid.

${ }^{35}$ Alon Mandimpu Nainggolan, "Model Diakonia Gereja di Tengah Pandemi Covid-19: Sebuah Upaya Mitigasi Bencana Non Alam,” Pute Waya: Jurnal Sosiologi Agama.

${ }^{36}$ Ibid. 
diakonia adalah upaya gereja dalam bidang praksis untuk berperan menolong orang yang berkekurangan. Para teolog ini (seperti Nimrot Doke Para dan teman-temannya, serta Alan Mandimpu Nainggolan) tampaknya menganggap diakonia karitatif kurang penting. Memang ada penilaian yang sedikit negatif terhadap diakonia karitatif, yaitu akan membuat penerima diakonia bersikap pasif, tetap berdiam diri dan hanya mengharapkan bantuan. Namun, bukankah memang hal ini dibutuhkan bagi orang-orang yang pada saat itu benar-benar membutuhkan. Yesus berkata kepada murid-murid-Nya: "Kamu harus memberi mereka makan" dalam kisah Yesus memberi makan lima ribu orang (Luk. 9:10-17). Dalam cerita Orang Kaya dan Lazarus yang Miskin (Luk. 16:1931) menggambarkan orang kaya yang tidak mau peduli terhadap Lazarus yang sedang lapar. Hal ini menggambarkan bahwa diakonia karitatif pun sangat penting sebagai jawaban nyata atas persoalan mereka. Sedangkan untuk diakonia transformatif sebenarnya juga merupakan bagian dari pemberdayaan untuk peningkatan ekonomi, maka diperlukan perhatian yang serius agar tidak terjerumus dalam semangat kapitalisme.

\section{Teologi Kepemilikan dan Fungsi Kekayaan Menurut Lukas}

Kesatu, Teologi Kepemilikan. Dalam Lukas 19:11-27 diceritakan perumpamaan tentang seorang bangsawan yang akan pergi dan suatu saat akan kembali. Sebelum keberangkatannya, ia memanggil sepuluh hambanya dan memberikan sepuluh mina kepada mereka (ay. 13). Perumpamaan ini memiliki kesamaan konsep tentang seorang tuan yang mempercayakan kekayaannya kepada hamba-hambanya di dalam Lukas 12:35-48 dan 16:1-9.

Dari ketiga teks ini, Kyoung-Jin Kim menangkap bahwa ada konsep tuan-budak dalam teologi Lukas. Dalam konsep ini ditunjukkan bahwa Lukas bermaksud untuk mendefinisikan hubungan yang tepat antara Tuhan (atau Yesus) dan orang-orang Kristen sebagai hubungan tuan-budak, bukan hanya hubungan guru-murid. Konsep hubungan tuan-budak ini muncul sebagai ciri-ciri mencolok yang membedakan dalam teologi Lukas. Kyoung-Jin Kim menggabungkan dua ciri khas Lukas ini, dan sebagai hasilnya, menyarankan paradigma baru bagi orang Kristen, yakni penatalayanan. Kemudian Kyoung-Jin Kim dapat mengidentifikasi persyaratan penatalayanan yang ada dalam pikiran Lukas, salah satunya adalah apa yang dimiliki seorang pengurus/ pelayan (budak) bukanlah miliknya, melainkan milik tuannya. ${ }^{37}$

Yang menjadi perhatian adalah bahwa apa yang dimiliki oleh hamba (budak) adalah bukan miliknya sebab, ia hanya diberikan oleh tuannya. Dalam hal ini terdapat makna teologis bahwa Allah yang digambarkan sebagai tuan (seorang bangsawan dalam

\footnotetext{
${ }^{37}$ Kyoung-Jin Kim, Stewardship and Almsgiving in Luke's Theology; JSNT, Sup.155 (Sheffield: Sheffield Academic Press, 1998), 285-286.
} 
perumpamaan sepuluh uang mina) adalah pemilik dari uang tersebut. Jadi dalam hal ini muncul teologi kepemilikan Tuhan.

Dari teologi kepemilikan Tuhan ini, maka muncul konsep bahwa bahwa kekayaan adalah anugerah Allah. Hal ini dapat dilihat dari ketiga teks di atas yang juga memperlihatkan bahwa para hambanya yang dipercayakan harta adalah hamba-hamba yang tidak memiliki harta. Para hamba tersebut tidak memiliki harta, dan kemudian si tuan memberikan uang (dalam Luk. 19:13) kepada mereka. Kata "memberikan" dalam Lukas 19:13 ini berasal dari kata "edoken" yang akar katanya adalah "didomi”. Didomi tidak hanya dapat diartikan memberikan, melainkan juga dapat diterjemahkan dengan kata mempercayakan atau menyerahkan. Kalimat dalam Lukas 19:13 dapat dipahami bahwa sebenarnya tidak ada tuntutan dari sang tuan kepada para hambanya untuk mengembalikan uang kepada tuannya. Dalam ayat 16-17 terlihat bahwa ketika hamba tersebut mengembangkan uang, hamba tersebut justru diberikan kekuasaan atas sepuluh kota. Hal ini menggambarkan bahwa tidak ada penarikan kembali uang itu dari sang tuan. Karena itu, berdasarkan kata dari "didomi" ini, maka tepat jika uang yang dipercayakan atau diserahkan kepada para hamba itu sebenarnya adalah anugerah dari sang pemilik.

Dalam analisis ini dapat dipahami bahwa uang yang merupakan gambaran dari kekayaan merupakan anugerah dari Allah yang digambarkan oleh sang tuan. Allah mempercayakan atau menyerahkan kekayaan kepada manusia untuk dapat dikelola dengan baik.

Allah juga menganugerahkan kekayaan kepada pribadi manusia. Dalam ketiga teks ini menggambarkan bahwa sang tuan menyerahkan aset kekayaannya kepada para hambanya itu secara pribadi. Mereka masing-masing diberikan bagiannya. Dalam Luk. 19:16 digambarkan bahwa hamba yang pertama telah menerima satu mina, dan dapat mengembangkannya menjadi sepuluh mina. Kemungkinan ini merupakan gambaran bahwa masing-masing hamba telah diberikan satu mina. Namun, mungkin hal ini tidak mendapat perhatian yang serius dari Lukas berapa jumlah uang mina yang diterima dari masing-masing hamba itu. Dalam perumpamaan ini menggambarkan bahwa uang mina tersebut telah diberikan kepada masing-masing hamba. Jadi, hal ini menerangkan bahwa kekayaan yang dianugerahkan Allah itu diberikan secara pribadi kepada manusia.

Pemahaman tentang kekayaan dipahami bahwa Allah memberikan kekayaan kepada masing-masing pribadi manusia. Ada dimensi kebersamaan dalam konsep kekayaan. Dimensi kebersamaan ini dapat dilihat dalam komunitas Kristen perdana di dalam Kisah Para Rasul 2:42-47. Di dalam kitab Kisah Para Rasul ini memberikan suatu gambaran cara hidup komunitas Kristen. Di dalam komunitas ini menunjukkan adanya persekutuan yang erat. Hal tersebut ditandai dengan adanya penggunaan kata koinonia (persekutuan). Kata koinonia menjelaskan tentang persamaan dan kesetaraan. Jadi, persekutuan yang terjalin di jemaat mula-mula tersebut adalah persekutuan yang terdapat persamaan dan kesetaraan. 
Persamaan dan kesetaraan tersebut ditunjukkan dalam ayat 44 dan 45. Pada ayat 44: "semua milik mereka adalah milik bersama" (hapanta koina), dan ayat 45: "dan selalu ada dari mereka yang menjual harta miliknya, lalu membagi-bagikannya kepada semua orang sesuai dengan keperluan mereka masing-masing." Di dalam ayat 43-47 banyak digunakan kata kerja imperfek. Tense imperfek menunjukkan bahwa peristiwa yang terjadi tidak hanya berhenti sampai pada waktu itu saja. Hal ini mengindikasikan bahwa menjual harta tidak dilakukan dalam satu waktu sekali sekaligus, tetapi secara berkala. Menjual harta di sini dilakukan dalam periode tertentu dan dapat terjadi lagi jika dibutuhkan. ${ }^{38}$ Hal ini juga dipertegas dengan penggunaan kata benda cherian yang sebelumnya telah didahului dengan adanya kata normatif maskulin singular, yakni kata tis. Dari kata ini mengandung pemahaman bahwa meskipun yang mereka miliki adalah milik bersama, namun hal itu terjadi ketika ada di antara mereka yang membutuhkan. Jadi, penjualan harta milik untuk kepentingan bersama ini terjadi ketika ada yang membutuhkan di antara anggota kelompok mereka.

Persekutuan dalam komunitas jemaat mula-mula ini menggambarkan adanya kepedulian diantara mereka. Persekutuan yang erat membangkitkan kepedulian mereka sampai pada tingkat kebutuhan materi, yang sampai pada akhirnya jalan yang mereka menjual harta milik mereka. Tindakan mereka untuk mengatasi kebutuhan materi ini merupakan cara mereka dalam mengatasi kesenjangan sosial di antara mereka (terlihat dalam ayat 44).

Kedua, Teologi Fungsi Kekayaan. Kekayaan dilihat dari fungsinya tergambarkan dalam Lukas 16:1-13 (dalam perumpamaan bendahara yang tidak jujur) dan 19:1-10 (dalam kisah Zakheus). Kedua kisah ini dapat menggambarkan fungsi kekayaan secara positif, yakni kekayaan digunakan dengan bijaksana untuk Kerajaan Allah. Dalam kisah bendahara yang tidak jujur, ia dapat menggunakan kekayaan untuk mempersiapkan masa depannya yang sudah ia prediksikan. Ia dapat bertindak secara bijaksana dengan kekayaan. Sama halnya yang dilakukan oleh Zakheus sang kepala pemungut cukai yang dipandang negatif oleh masyarakat pada umumnya. Namun, ia dapat menggunakan kekayaan untuk Kerajaan Allah. Ia berinisiatif untuk mengembalikan apa yang selama ini sudah ia peras, dan membagikannya kepada orang miskin.

Pandangan positif terhadap fungsi kekayaan ini mendorong pembaca Lukas untuk menjadi alat Kerajaan Allah melalui harta milik mereka. Mengingat bahwa penerima Injil Lukas salah satunya adalah Teofilus yang merupakan orang saleh takut akan Allah dan juga memiliki harta kekayaan, penggunaan harta milik secara positif tergambarkan dari sikap Teofilus ini yang merupakan penyokong penulisan Lukas. Tentu tidak hanya Teofilus ini saja yang mempraktikkan sikap hidup ini dalam komunitas Lukas, sebab Teofilus juga merupakan representasi dari komunitas Lukas yang terdiri dari orang-orang mapan yang takut akan Allah.

${ }^{38}$ Lihat juga dalam penjelasan C.K. Baret, A Critical and Exegetical Commentary on Apostles 1 (Edinburgh: T. \& T. Clark, 1994), 169. 
Dalam Injil Lukas digambarkan juga tentang kekayaan yang tidak difungsikan dengan baik untuk orang lain, namun justru membawa pada sikap ketamakan. Sikap ketamakan karena kekayaan ini menimbulkan konflik antara orang-orang kaya dan orang-orang miskin. ${ }^{39}$ Dalam konteks ini, penelitian Esler mengenai keberadaan sosioekonomi orang-orang kaya dan miskin dalam Roma Timur di abad pertama dapat menolong untuk melihat kesengsaraan dan kesedihan orang-orang miskin dalam masa Lukas, dan bagaimana sikap arogansi dan egosentris orang-orang kaya. ${ }^{40}$ Sikap arogansi dan egosentris orang-orang kaya menjadikan diri mereka tamak. Hal inilah yang menjadi tegoran dari Lukas bagi mereka, sehingga Lukas banyak menyajikan teks-teks dalam kitab Injilnya yang berkenaan dengan sikap orang-orang kaya ini.

Teks-teks Lukas yang berkaitan dengan soal kekayaan yang dapat membawa dampak ketamakan, misalnya dalam Lukas 6:24 yang menggambarkan bahwa kekayaan menentukan penghiburan atau kebahagiaan seseorang. Di dalam Lukas 12:13-21 juga menggambarkan ketergantungan orang kaya terhadap kekayaannya, sehingga ia ingin mendapatkan yang sama atau bahkan lebih dari saudaranya. Hal ini menandakan adanya sikap ketamakan dan iri hati yang dimiliki oleh orang kaya tersebut. Bagitu juga dalam Lukas 15:11-32 menggambarkan keegoisan baik itu dalam diri anak bungsu maupun anak yang sulung. Kedua-duanya tamak terhadap kekayaan. Si bungsu meminta bagian sebelum waktunya. Sedangkan si sulung merasa iri atas pesta yang diselenggarakan oleh bapanya karena kembalinya si bungsu. Si sulung menganggap ia tidak mendapatkan apa pun dari bapanya. Kedua anak ini sama-sama berorientasi pada kekayaan dan untuk kepentingan mereka sendiri.

Contoh lain misalnya dalam Lukas 16:19-31 digambarkan tentang orang kaya yang selalu menggunakan harta kekayaannya untuk dirinya sendiri. Orang kaya tersebut tidak mau menggunakan kekayaannya untuk menghilangkan rasa lapar orang miskin Lazarus yang miskin. Padahal hidupnya selalu dengan kemewahan. Lukas 18:18-27 juga menggambarkan hal yang sama. Pertanyaannya orang kaya tentang bagaimana cara memperoleh hidup yang kekal dijawab oleh Yesus dengan jawaban yang mencengkam dan tidak mungkin dilakukan olehnya. Harta kekayaan lebih menguasai dirinya sehingga ia pun tidak mau membagikan hartanya kepada orang lain.

Dari rangkaian materi Lukas yang memperlihatkan ketamakan orang-orang kaya ini manandakan bahwa orang dihukum bukan karena ia adalah orang kaya. ${ }^{41}$ Yang menjadi persoalan adalah penggunaan atas kekayaan tersebut. Kekayaan atau orang

${ }^{39}$ Bambang Subandrijo, Menyingkap Pesan-pesan Perjanjian Baru (Bandung: Bina Media Informasi, 2010), 139.

${ }^{40}$ Philip Francis Esler, Community and Gospel in Luke-Acts; The Social and Political Motivation of Lucan Theologi, Monograph Series/ Society for New Testament Studies; 57 (Cambridge: Cambridge University Press, 1987), 183-187.

117.

${ }^{41}$ Craig L. Bomberg, Tidak Miskin Tetapi Juga Tidak Kaya (Jakarta: BPK Gunung Mulia, 2011), 
kaya menjadi berada dalam posisi salah di hadapan Allah karena penggunaan harta kekayaannya yang tidak benar. Harta kekayaan hanya digunakan untuk diri sendiri dan kepentingan sendiri.

Dengan demikian, Lukas manaruh bahan-bahannya tentang kekayaan ini agar para pembacanya yang juga terdiri dari orang-orang kaya dapat secara benar menggunakan harta kekayaan mereka. Nilai fungsi kekayaan menjadi bagian yang penting dalam tulisan Lukas yang berguna untuk menekan ketamakan dari orang-orang kaya dan menolong orang-orang yang miskin.

\section{Teologi Kepemilikan dan Fungsi Kekayaan Menurut Lukas sebagai Upaya Mengatasi Kemiskinan di Indonesia}

Sikap ketamakan ditemukan dalam beberapa teks dalam tulisan Lukas (Lukas 6:24, 12:13-21, 15:11-32, 16:19-31, 18:18-27). Ketamakan dalam tulisan Lukas ini juga merupakan gambaran kapitalisme. Nilai kapitalisme yang berbahaya adalah sikap yang tidak memiliki kepuasan untuk terus mendapatkan kekayaan.

Pemberdayaan dan kewirausahaan yang mendorong jemaat untuk meningkatkan perekonomian mereka, dapat terjebak pada bahaya kapitalisme yang terus-menerus ingin meningkatkan kekayaan, baik itu dengan bekerja keras maupun dengan spiritualitas ugahari yang tanpa disadari dapat menimbulkan jiwa keserakahan dan egosentrisme yang tinggi. Untuk mengendalikan hal ini, diperlukan dasar teologi kepemilikan yang dapat menjadi pedoman di dalam mendasari pelaksanaan pemberdayaan dan kewirusahaan.

Teologi kepemilikan menurut Lukas melahirkan tiga konsep. Pertama, kepemilikan mutlak atas kekayaan adalah Allah. Kekayaan yang dimiliki oleh manusia hanya merupakan anugerah dari Allah. Jadi, meskipun manusia telah berusaha untuk mendapatkan kekayaan yang sebanyak-banyaknya, kekayaan tersebut adalah anugerah Allah.

Kedua, manusia memiliki tugas untuk mengembangkan kekayaan yang Tuhan anugerahkan. Hal ini mengandung arti bahwa manusia harus bekerja untuk menyambut anugerah kekayaan Allah. Pemberdayaan dan kewirausahaan yang bertujuan untuk meningkatkan kekayaan tidaklah salah. Menjadi suatu kesalahan jika fokus hidupnya hanya untuk mencari dan terus mengusahakan kekayaan sampai pada akhirnya jatuh pada sikap ketamakan.

Di sisi lain, dengan konsep bahwa manusia harus mengembangkan kekayaan dapat menjadi dasar bagi konsep diakonia agar tidak mengakibatkan orang yang menerima diakonia akan terus berdiam menantikan belas kasihan. Semangat untuk menyambut anugerah kekayaan Allah dalam bekerja harus menjadi konsep yang dikembangkan dalam berdiakonia.

Ketiga, kekayaan dimiliki secara pribadi dan juga komunal. Maksudnya adalah Allah telah menganugerahkan kekayaan kepada manusia secara pribadi, dan juga 
kepemilikan komunal. Kepemilikan komunal menghindari penumpukkan kekayaan pada seseorang. Konsep kepemilikan komunal melengkapi teologi fungsi kekayaan. Kekayaan yang dimiliki oleh seseorang secara pribadi juga harus didistribusikan kepada orang lain yang membutuhkan. Melalui pemahaman ini, sirkulasi kekayaan akan terjadi, sehingga dapat mengakibatkan keseimbangan dalam masyarakat.

Teologi kepemilikan dan fungsi kekayaan secara ringkas mengandung makna bahwa pada hakekatnya pemilik mutlak kekayaan adalah Allah. Allah menganugerahkan kekayaan kepada masing-masing orang. Namun, kekayaan yang dianugerahkan kepada masing-masing orang tersebut juga memiliki dimensi komunal, yang memuwudkan nilai fungsi dari kekayaan. Jika digambarkan, maka akan membentuk suatu pola vertikal demikian:

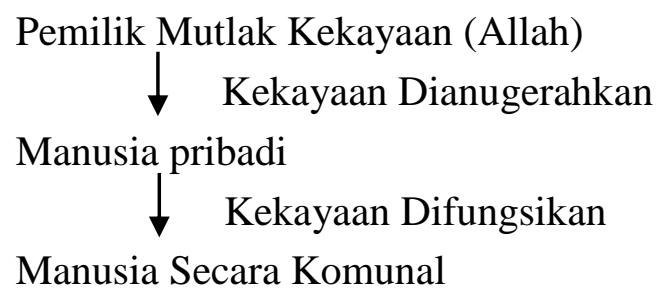

Agar konsep ini terimplentasikan, maka gereja perlu membuat suatu upaya pengentasan kemiskinan yang tidak hanya berbasis pada kehidupan individual, melainkan juga komunal. Inilah yang menjadi kontribusi teologi kepemilikan dan fungsi kekayaan dalam Lukas, yaitu kehidupan komunal yang dapat memfungsikan kekayaan pribadi untuk kepentingan orang lain. Kehidupan komunal demikian dapat menekan penumpukan kekayaan pribadi dan justru dapat menciptakan kesimbangan dalam hal kepemilikan pribadi, sehingga tidak tercipta jurang pemisah antara yang kaya dan miskin.

Pemberdayaan, kewirausahaan yang selama ini terjadi hanya sebatas pada dorongan untuk meningkatkan kekayaan secara individu. Jika demikian yang terjadi, kesenjangan antara yang miskin dan yang kaya akan tetap terus ada. Pengentasan kemiskinan tidak hanya melibatkan orang-orang miskin (sebagaimana target dari pemberdayaan dan kewirausahan), tetapi juga melibatkan orang-orang yang memiliki kekayaan yang lebih, sebab gereja tidak hanya terdiri dari orang-orang miskin, tetapi juga orang-orang kaya. Kedua-duanya perlu untuk dilibatkan agar tercipta kehidupan bersama. Di sinilah letak dari fungsi kekayaan, yaitu untuk membentuk komunitas bersama. Sedangkan teologi kepemilikan terletak pada rasa untuk melihat bahwa kekayaan yang mereka miliki itu adalah anugerah Allah, karena itu harus dinikmati secara bersama.

Akan tetapi, dalam teologi ini tidak membatasi orang secara pribadi untuk memiliki kekayaan, sebab dalam teologi kepemilikan juga mengandung makna bahwa Allah menganugerahkan kekayaan secara pribadi, dan manusia diperintahkan untuk 
mengembangkan anugerah kekayaan Allah tersebut. Hanya kemudian kekayaan itu harus juga difungsikan agar terhindar dari sifat ketamakan dan tercipta kehidupan yang seimbang di dalam kehidupan bersama.

Jadi, dengan teologi kepemilikan dan fungsi kekayaan mengatasi bahaya yang dimunculkan dari pengentasan kemiskinan yang berbasis pada pemberdayaan, kewirausahaan dan diakonia. Teologi kepemilikan dapat berguna untuk menekan keserakahan akibat semangat untuk menjadi kaya. Sedangkan teologi fungsi kekayaan dapat membangun sikap solidaritas antar manusia, sehingga dapat mempergunakan kekayaan untuk kepentingan bersama. Dengan demikian, pelaksanaan berbagi harta (seperti diakonia) dapat terjadi dalam rangka untuk mencapai hidup bersama dan seimbang, sehingga tidak ada jurang antara yang kaya dan yang miskin. Menurut penulis, teologi kepemilikan dan fungsi kekayaan dapat menjadi kendali atas bahaya yang dapat ditimbulkan dari pelakasanaan pemberdayaan, kewirausahaan dan diakonia.

\section{Kesimpulan}

Teologi kepemilikan yang didapat dari tulisan Lukas menekankan bahwa Allah adalah pemilik mutlak dari kekayaan. Kekayaan harta yang dimiliki manusia sebenarnya adalah milik Allah, dan dianugerahkan-Nya kepada manusia. Konsep ini perlu mendasari konsep pemberdayaan dan kewirausahaan yang dapat saja jatuh pada bahaya kapitalisme yang mengarah kepada ketamakan. Pada dasarnya, Allah memberikan kekayaan kepada manusia secara pribadi. Hal ini mengandung arti bahwa setiap pribadi manusia memang boleh untuk memiliki dan mengusahakan kekayaan mereka. Namun, kekayaan itu juga mempunyai nilai komunal, yakni dalam arti karena pemilik mutlak kekayaan adalah Allah, maka kekayaan itu juga harus dirasakan oleh orang lain. Dengan demikian, hal ini juga mengandung nilai fungsi dari kekayaan tersebut, yaitu mempergunakan kekayaan untuk orang lain yang membutuhkan. Selain itu, pemberdayaan, kewirausahaan dan diakonia tidak hanya bekerja pada aras individualistik, melainkan juga memiliki dimensi komunal yang melibatkan orang-orang miskin dan kaya, sehingga dapat menciptakan kehidupan bersama tanpa adanya kesenjangan sosial. Dengan demikian, kitab Lukas memberikan kontribusi pemikiran tentang teologi kepemilikan dan fungsi kekayaan. Kontribusinya adalah dalam tulisan Lukas terdapat adanya suatu pola sistemik yang dilahirkan dari teologi kepemilikan dan fungsi kekayaan. Pola yang sistemik tersebut dapat menyumbangkan pemikiran agar gereja dapat membuat suatu sistem pengentasan kemiskinan yang tidak hanya bekerja pada aras individualistik, melainkan juga memiliki dimensi komunal yang melibatkan orang-orang miskin dan kaya untuk dapat menciptakan komunitas yang tanpa kesenjangan sosial. 


\section{Referensi}

BPS. Berita Resmi Statistik: Profil Kemiskinan Di Indonesia Maret 2020, No. 56/07/Th. XXIII, 15 Juli 2020.

Bomberg, Craig L. Tidak Miskin Tetapi Juga Tidak Kaya. Jakarta: BPK Gunung Mulia, 2011.

Cassidy, Richard J. Society and Politic in The Acts of the Apostles. Maryknoll: Orbis Books, 1987.

Esler, Philip Francis. Community and Gospel in Luke-Acts; The Social and Political Motivation of Lucan Theologi, Monograph Series/ Society for New Testament Studies; 57. Cambridge: Cambridge University Press, 1987.

Febriana, Mariani. "Pietas dan Caritas: Pelayanan Diakonia Sebagai Suatu Implementasi Kepedulian Sosial Gereja Untuk Menolong Meretas Angka Kemiskinan Di Indonesia," Jurnal Theologi Aletheia, Vol. 16, No. 7. September 2014.

Jonge, Christian de. Menuju Keesaan Gereja: Sejarah Dokumen-dokumen dan tematema gerakan oikumenis. Jakarta: BPK Gunung Mulia, 2006.

Julianto, Simon. "Kewirausahaan Jemaat: Sebuah Alternatif Berteologi," Waskita, Jurnal Studi Agama dan Masyarakat.

Kothari, C.. Research Methodology: Methods and Techniques. New Delhi: New Age International Limited Publisher, 2004.

Kim, Kyoung-Jin. Stewardship and Almsgiving in Luke's Theology; JSNT, Sup.155 Sheffield: Sheffield Academic Press, 1998.

Likumahwa,George Marthen, John A. Titaley dan Steve Gaspersz, "Keluar dari Kemiskinan: Studi Pembangunan dan Pemberdayaan Jemaat di Dususn Siahari, Kecamatan Seram Utara Timur," Arumbae: Jurnal Ilmiah Teologi dan Studi Agama, Vol. 2, No. 1. 2020.

Lough, Josehph W.H. Weber and the Persistence of Religion: Social Theory, Capitalism, and the sublime. London and New York: Routledge, 2006.

Nababan, Tongam Sihol. "Gereja dan Kesejahteraan warga dalam Perspektif Ekonomi Kerakyatan”, MPRA (Munich Personal Repec Archive). 17 April 2011.

Nainggolan, Alon Mandimpu. "Model Diakonia Gereja di Tengah Pandemi Covid-19: Sebuah Upaya Mitigasi Bencana Alam Non Alam," Putewaya: Jurnal Sosiologi Agama, Vol. 1, No. 1 (2020), 40-45.

Noor, Munawar. "Pemberdayaan Masyarakat," Jurnal Ilmiah CIVIS, Vol. I, No. 2. Juli 2011.

Nugroho, Fibry Jati. "Gereja dan Kemiskinan: Diskursus Peran Gereja di Tengah Kemiskinan," Evangelikal: Jurnal Teologi Injili dan Pembinaan Warga Jemaat, Vo. 3, No. 1. Januari 2019.

Para, Nimrot Doke, dkk.. "Peran Gereja dalam Transformasi Pelayanan Diakonia," Jurnal Teologi Kontekstual Indonesia, Vol. 1, N. 1. 2020. 
PGI. Dokumen Keesaan Gereja (DKG-PGI) 2019-2024. Jakarta: BPK Gunung Mulia, 2020.

Saragih, Erman S.."Fungsi Gereja Sebagai Entrepreneurship Sosial dalam Masyarakat Majemuk," Kurios: Jurnal Teologi dan Pendidikan Agama Kristen, Vol. 5, No. 1. April 2019.

Subandrijo, Bambang. Menyingkap Pesan-pesan Perjanjian Baru. Bandung: Bina Media Informasi, 2010.

Sumbung, Grace, dkk., "Peran Gereja dalam Peningkatan Ekonomi Masyarakat di Tomohon Sulawesi Utara," Jurnal Wacana, Vol. 15, No. 4. 2012.

Tan, Wee-Liang, John Williams, and Teck-Meng Tan, "Defining Social in Social Enterpreneurship: Altruisme and Entrepreneurship," International Entrepreneurship and Management Journal. 2005.

Weber, Max. The Protestant Ethic and the Spirit of Capitalism. London and New York: Routledge, 2001. (terjemahan dalam Bahasa Ingris). 